\title{
A Quantitative Approach Towards Human-Thermal Vulnerability
}

Jayashree Sen ( $\nabla$ jayashree.sen14@gmail.com )

Ramakrishna Mission Vivekananda Educational and Research Institute https://orcid.org/0000-00034298-2885

\section{Pranab Kumar Nag}

Ramakrishna Mission Vivekananda Educational and Research Institute

\section{Research Article}

Keywords:

Posted Date: January 31st, 2022

DOI: https://doi.org/10.21203/rs.3.rs-166241/v1

License: (c) (1) This work is licensed under a Creative Commons Attribution 4.0 International License. Read Full License 


\title{
A Quantitative Approach towards Human- Thermal Vulnerability
}

\author{
JAYASHREE SEN \\ Teaching cum Research Assistant, \\ School of Environment and Disaster Management, \\ IRDM Faculty Centre, \\ Ramakrishna Mission Vivekananda Educational and Research Institute, \\ Narendrapur, Kolkata - 700103, India \\ jayashree.sen14@gmail.com
}

PRANAB KUMAR NAG,

Professor,

School of Environment and Disaster Management,

IRDM Faculty Centre,

Ramakrishna Mission Vivekananda Educational and Research Institute,

Narendrapur, Kolkata - 700103, India

pranabnag@yahoo.com

\section{Correspondence address}

Jayashree Sen

jayashree.sen14@gmail.com

School of Environment and Disaster Management, IRDM Faculty Centre,

Ramakrishna Mission Vivekananda Educational and Research Institute,

Narendrapur, Kolkata - 700103, India 


\section{Abstract}

Human vulnerability towards extreme heat exposure has generally been expressed as the cumulative expression of social, demographic, agricultural, environmental factors. Besides this, behavioural and physiological characteristics of individual may be responsible for significant differences in thermal perception and health effects towards extreme heat. The present endeavour is towards the identification and derivation of the quantitative scale of human-thermal vulnerability considering the social, human and thermal indicators. The study illustrates district-wise and village-wise human vulnerability considering different conventional indicators from social and environmental domain along with the factors accountable towards human warmth. The vulnerability was assessed, as representative for the state of Punjab, Haryana and West Bengal of India. Principle Component Analysis (PCA) was used as means of aggregating diverse indicators and to develop clusters of different variables as the respective principal components. The analysis indicated the utility of the expression of different types of vulnerability and the reasons to consider various indicators and their relative weightages. Accordingly, a quantitative scale of human-thermal vulnerability is arrived at, considering the social, human and thermal indicators. 


\section{Declarations}

The authors declare that they have no known competing financial interests or personal relationships that could have appeared to influence the work reported in this paper.

\section{Funding}

The study was undertaken with due approval and internal funding of the Ramakrishna Mission Vivekananda Educational \& Research Institute. Partial assistance was received from the University Grant Commission, India under NET Junior Research Fellowship (Jayashree Sen). The study involve human data analysis with their ethical concern.

\section{Conflict of interest}

The authors declare that they have no conflict of interest.

\section{Authors' contributions}

Both the author has made a significant contribution towards the concept of the article, the methodological development, analysis, and interpretation of the data. 


\section{Acknowledgment}

The authors gratefully acknowledge the kind permission of the Vice Chancellor of the University (Ramakrishna Mission Vivekananda Educational \& Research Institute, Deemed to be University) in undertaking the study. Partial financial support of the University Grant Commission under NET Junior Research Fellowship (JRF) is gratefully acknowledged. 


\section{Introduction}

Worldwide concerns have been raised about the potential impacts of the changing climate, climate variability and the associated weather extremes (Aubrecht and Özceylan, 2013). Evidences reaffirm that extreme climatic condition makes the human being more and more vulnerable (Patz et al., 2005; Kjellstrom et al., 2016). Research has been carried out in different communities to assess the level of vulnerability towards climatic hazards (Rabindranath et al., 2011; Walker et al., 2014; Zein and Tonmoy, 2015). The relationship is apparent about the facts of the increasing climatic stress on human health and wellbeing, particularly among people in the tropical and sub-tropical zones (Nag et al., 2009; Sen and Nag 2019). However, people have innate ability to adapt physiologically and technologically towards the changing climatic condition up to a certain limit (O'Brien et al., 2004). Beyond which high temperature exacerbates human vulnerability in terms of mortality, morbidity and health related hazards (Reid et al., 2009). Prolonged exposure in extreme heat intensifies the health risk due to elevated physiological responses and inadequacy in the thermoregulatory controls that manifest into a varied forms of heat disorders and injury (Parsons, 2009). Excessive storage of heat in the body due to inappropriate evaporative heat loss (Zhao et al., 2009) in the moist thermal environment significantly decrease labour productivity (Dunne et al., 2013). Several studies (Sahu et al., 2013; Zander et al., 2015; Krishnamurthy et al., 2017) emphasized on the profound effect of heat exposure over worker's productivity. Different human thermal indices, such as WBGT (Wet Bulb Globe Temperature) (Kjellstorm et al., 2009; Nag et al., 2009), Heat Index (a combined measure of temperature and relative humidity) were proven as useful (Aubrecht and Özceylan, 2013; Rosenthal et al., 2014) in the identification of 
heat related stress and disorders. Exposure limit of such indices signifies the degree of vulnerability in the extreme climatic conditions (Lundgren et al., 2014).

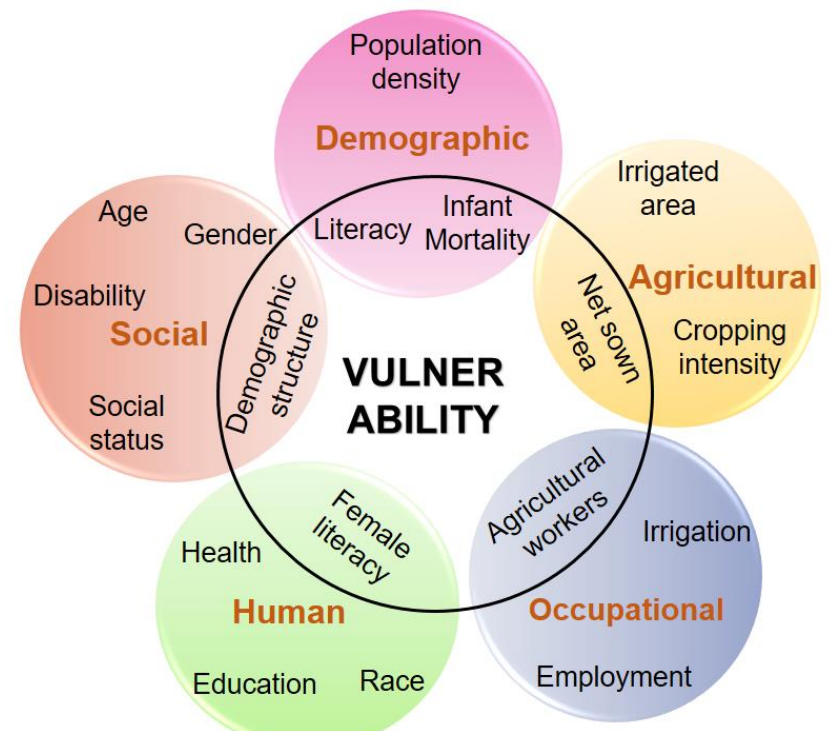

Figure 1. Indicators used to assess vulnerability

Concerning heat exposure, researchers from different domain explored the level of vulnerability linking heat related health issues with social and environmental factors (Harlan et al., 2006; Reid et al., 2009; Jhonson et al., 2012). Over the decade, several parameters and approaches have been utilized in an alternative way to assess different kind of vulnerability such as social, demographic and agricultural vulnerability (Figure 1). Such parameters have been chosen to describe sensitivity and adaptive capacity of the exposed population, with least consideration of individual physiological, psychological (Ford et al., 2006) and behavioural characteristics (Vincent, 2004). Human being exposed towards similar climatic condition may experience different perception and health effects, leading to variations in the vulnerability (Nikolopoulou and Steemers, 2003; Sen and Nag, 2019b). Undoubtedly, the assessment of vulnerability considering the tolerance, sensitivity, and adaptive capacity of the individual in tropical climatic area is scanty (Nag et al., 2013). Needless to mention 
that establishing the degree of vulnerability of a population towards heat exposure is a complex phenomenon. The challenge remains in defining the potentials of risk due to heat exposure in individual level involving a combination of location-dependent physiological variables, social and environmental factors. This study is a modest endeavour to arrive at the degree of vulnerability integrating different facets of vulnerability. Such an approach may be applied to varied regional and local perspectives.

\section{Methods and materials}

In the present contribution, vulnerability assessment was done incorporating multidimensional data. Moreover, individual physiological and behavioural parameters were integrated along with the conventional parameters (as mentioned in Figure 1) over diverse spatial scale. To represent a more comprehensive characterization of vulnerability 28 districts of two northwestern states of India (i.e., Punjab and Haryana) and the rural sector of West Bengal in eastern India (Figure 2) was taken into consideration.

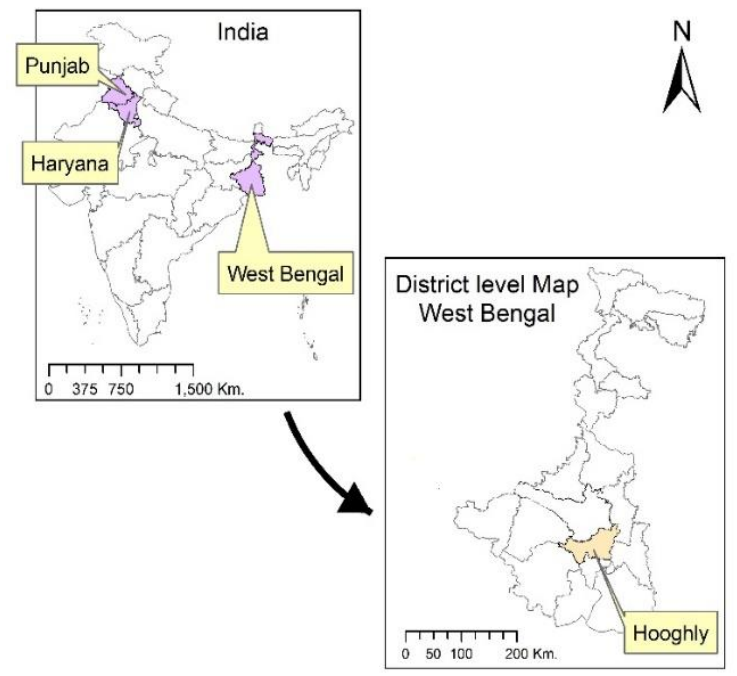

Figure 2. Location Map of the study area 
District wise vulnerability analysis:

District wise social, human, as well as climatic vulnerability, were assessed for 28 districts of Punjab and Haryana. These two Indian states were moderately developed according to $2017 \mathrm{HDI}$ ranking (2017 HDI value $>0.7$ ). Most of the region of these two states experience semi-arid steppe climate, according to Köppen (1919) climate classification, which indicates extreme weather throughout the year.

A set of 18 widely used social variables (Table 1) were taken into account to assess the district wise social vulnerability of these states. Such indicators have distinct functional effect in the overall vulnerability. Data were gathered from the Indian statistical abstract (Census 2011). Over the decades, the cumulative influence of such indicators was found to be useful in the assessment of the degree of vulnerability in a particular time and place (Leichenko et al., 2004; Gbetibouo and Ringler, 2009, Rabindranath et al., 2011). Researchers adopted similar technology like PCA (Principal Component Analysis) to derive clusters of non correlated variables (Ravindranath et al. 2011; Abson et al., 2012). Normalization technique was applied to make the indicator unit free and maintain the competency of combining multiple indicators prior to the analysis. According to the component loadings and component score coefficients, the normalized weights of the principal components were transformed into a summated loading of components to express district wise social vulnerability. 
Table 1: Parameters used to analyze district wise vulnerability

\begin{tabular}{|l|l|c|}
\hline \multicolumn{1}{|c|}{ Indicators } & \multicolumn{1}{|c|}{ Description } & $\begin{array}{c}\text { Increase (+) or } \\
\text { decrease (-) } \\
\text { vulnerability }\end{array}$ \\
\hline Population density & $\begin{array}{l}\text { Due to higher population density, resources } \\
\text { cannot be used at its' optimum level (Islam } \\
\text { Nazrul et al., 2013). }\end{array}$ & + \\
\hline Female literacy & $\begin{array}{l}\text { Higher female literacy rate in society helps } \\
\text { to reduce fertility rate, infant mortality, as } \\
\text { well as gender bias (Leichenko et al., 2004). }\end{array}$ & - \\
\hline Rural population & $\begin{array}{l}\text { Overpopulation in rural areas creates } \\
\text { pressure over natural resources (Rao et al., } \\
\text { 2013). In such areas, more people are } \\
\text { directly exposed to extreme climatic events } \\
\text { (Gbetibouo et al., 2009). }\end{array}$ & + \\
\hline $\begin{array}{l}\text { Disabled } \\
\text { population }\end{array}$ & $\begin{array}{l}\text { Disable persons are not able to respond } \\
\text { individually at the time of disaster (Rygel et } \\
\text { al., 2006). Also, difficulty persists in the } \\
\text { specific identification of the physically or } \\
\text { mentally disabled person (Dwyer et al., } \\
\text { 2004). }\end{array}$ & + \\
\hline Net area sown & $\begin{array}{l}\text { Unemployment signifies towards the higher } \\
\text { proportion of people below the poverty line. } \\
\text { Lack of support systems elevates the level } \\
\text { of vulnerability in situations of crisis and } \\
\text { disaster (Gbetibouo and Ringler, 2009; } \\
\text { Flanagan et al., 2011). }\end{array}$ & $+\begin{array}{l}\text { More sown area indicates more agricultural } \\
\text { dependency and therefore enhance the } \\
\text { vulnerability towards natural calamity (Rao } \\
\text { et al., 2013; ICAR report, 2013) }\end{array}$ \\
\hline Unemployed \\
person
\end{tabular}




\begin{tabular}{|c|c|c|}
\hline $\begin{array}{l}\text { Total cropped } \\
\text { area }\end{array}$ & $\begin{array}{l}\text { The larger area under total crop production } \\
\text { indicates the improved adaptive capacity } \\
\text { (Islam Nazrul et al., 2013). }\end{array}$ & - \\
\hline $\begin{array}{l}\text { Average size of } \\
\text { landholding } \quad(<2 \\
\text { hec.) }\end{array}$ & $\begin{array}{l}\text { Small agricultural landholding indicates the } \\
\text { marginal and small farmers (Rabindranath } \\
\text { et al., 2011). }\end{array}$ & + \\
\hline Net irrigated area & $\begin{array}{l}\text { Irrigation is a vital adaptation-enabler as it } \\
\text { enables farmers to save crops during dry } \\
\text { spells or droughts. It is also strongly related } \\
\text { to technology adaption (Rao et al., 2013). }\end{array}$ & - \\
\hline Fallow land & $\begin{array}{l}\text { Fallow land indicates towards the } \\
\text { deforestation, soil erosion and increment of } \\
\text { pollution level (Vezina et al. 2006). }\end{array}$ & + \\
\hline Area under forest & $\begin{array}{l}\text { Forest area is an essential primary activity } \\
\text { of people and produces various jobs } \\
\text { (Fatemi et al., 2017). }\end{array}$ & - \\
\hline $\begin{array}{l}\text { Fertilizer } \\
\text { consumption }\end{array}$ & $\begin{array}{l}\text { Consumption of fertilizers in agricultural } \\
\text { land is an indicator of sufficient food } \\
\text { production and hence indicates the } \\
\text { adaptive capacity (Rabindranath et al., } \\
\text { 2011; Rao et al., 2013). }\end{array}$ & - \\
\hline $\begin{array}{l}\text { Household having } \\
\text { electricity }\end{array}$ & $\begin{array}{l}\text { The facility of domestic electricity helps to } \\
\text { determine the overall development (Rao et } \\
\text { al., 2013). }\end{array}$ & - \\
\hline $\begin{array}{l}\text { Total metal road } \\
\text { length }\end{array}$ & $\begin{array}{l}\text { It is an indicator of good accessibility in the } \\
\text { market place and helps to integrate the } \\
\text { industries (Rao et al., 2013). }\end{array}$ & - \\
\hline $\begin{array}{ll}\text { Total } & \text { Govt. } \\
\text { employee } & \end{array}$ & $\begin{array}{l}\text { In terms of money and other competencies, } \\
\text { people engaged in government sectors } \\
\text { have more security benefit than others } \\
\text { (Cutter et al., 2003, Fatemi et al., 2013) }\end{array}$ & - \\
\hline Cultivator & $\begin{array}{l}\text { People engaged in cultivation have the } \\
\text { least scope to opt for other occupation due } \\
\text { to the lack of knowledge and expertise in } \\
\text { other organized sectors (Gbetibouo and } \\
\text { Ringler, 2009) }\end{array}$ & + \\
\hline
\end{tabular}


The climatic vulnerability was ascertained in the form of thermal stress as depicted by different human-thermal indices. District wise climatic vulnerability was visualized according to the stress level of the internationally approved standard human-thermal indices, WBGT (Wet Bulb Globe Temperature) (ISO 7243:2003). This index is the combination of the wet bulb, dry bulb and globe temperature. Meteorological data were obtained from the automatic weather stations (AWS), of the India Meteorological Department (IMD). Primarily, the analysis was done from the data of 28 AWS for 28 individual districts of Punjab and Haryana. In the present analysis, meteorological data was compiled for a particular time (6 UTC) at every alternative day, over a period of 1 year, i.e., from July'15 to June' 16 . The data included ambient temperature $\left(T_{a}\right)\left({ }^{\circ} \mathrm{C}\right)$, dew point temperature $\left(\mathrm{T}_{d}\right)\left({ }^{\circ} \mathrm{C}\right)$, mean sea level pressure (mslp) $(\mathrm{hPa})$, and wind speed (v) (knot). Other climatic parameters like relative humidity $(\mathrm{RH})$, wet bulb temperature $\left(T_{w}\right)$, saturated (svp) and unsaturated vapor pressure (vp), globe temperature $\left(T_{g}\right)$, mean radiant temperature (MRT), etc., were computed based on the conventional formula (Sen and Nag, 2019). Some districts were excluded from the analysis due to non-availability or non-uniformity of the meteorological data.

Further other conventional human thermal indices PMV (Predicted Mean Vote) and SET* (Standard Effective Temperature) were also taken into account with the social indicators to assess the district wise overall human vulnerability. Fanger (1970) proposed the predicted mean vote (PMV) using individual perception and sensation to study the comfort level. SET* is an improved version of thermal indices (Gagge et al., 1986) and use the mechanism of the CFD model (Lin et al., 2008). To compute these two indices using RayMan model Ver. 1.2 (Matzarakis et al., 2010) the required human parameters were set at body surface area $\left(1.47 \mathrm{~m}^{2}\right)$, clothing value $(0.4 \mathrm{clo})$ and 
metabolic rate $\left(50 \mathrm{~W} / \mathrm{m}^{2}\right)$ (Nag et al., 2009). Again, the normalized value of these social and meteorological variables was treated for PCA (Principal Component Analysis) to achieve the degree of human vulnerability.

Village level vulnerability analysis:

Village wise vulnerability was analyzed using a survey-based technique and generation of data from 22 villages of the rural areas of Hooghly districts of the state of West Bengal in eastern India. Large population of this area is habitually engaged in farming activities. To ensure the outdoor exposure he study period was chosen during the months of November to April 2015 to 2017.

Social data were obtained from Census 2011 for the selected villages to achieve the degree of social vulnerability. 28 variables (Table 2) were treated to assess the social vulnerability of these villages adopting the similar methodology of the PCA technique. The relevance of these social variables in vulnerability study has already been briefly described. For the micro-region vulnerability assessment, some basic amenities and assets parameters were also considered from the census data in correspondence to each village. Percentage of these parameters in the individual villages denotes the living standards. 
Table 2: Indicators to assess village wise social vulnerability

\begin{tabular}{|l|}
\hline Social indicators \\
\hline - Total population \\
- Temale literacy \\
- Total main worker \\
- Cultivator \\
- Forest area \\
- Net area sown \\
- Unigated area \\
- Canal area area \\
- Culturable waste land \\
- Fallow land \\
\hline
\end{tabular}

\begin{tabular}{|l|}
\hline Household amenities \& assets \\
\hline - Concrete roof \\
- Burnt brick wall \\
- Sufficient rooms \\
- Permanent house \\
- Ownership status of house \\
- Electric facility \\
- Winking water facility \\
- Kitchen facility \\
- Latrine facility within the premises \\
- Improved pit latrine \\
- LPG/PNG fuel \\
- Television \\
\hline
\end{tabular}

Observations of over 1000 people were considered in the assessment of the human thermal vulnerability for the selected villages. Subjective and objective measurements, such as, height, weight, body temperature, heart rate of the surveyed population were obtained at the time of field investigation of the mentioned villages. The objective measurements and the perceived responses recorded after taking ethical consent of the workers for their participation in the study. The environmental parameters included dry-bulb $\left(T_{a}\right)$ and wet bulb temperature $\left(T_{w b}\right)$ measured by the dry and wet bulb thermometer, and wind-speed ( $v$ ) by an anemometer. Other 
parameters like relative humidity and globe temperature were calculated using the conventional formulae.

Based on the environmental and biophysical parameters (Table 3), the human thermal vulnerability was yielded for the individual person applying a similar methodology of PCA analysis. Since engaging the same sample of population covered during the field survey in an individual village was not within the control of the investigator, the average degree of human thermal vulnerability of the village dwellers was depicted as the village wise thermal vulnerability. 
Table 3: Biophysical \& environmental parameters obtained from the village survey

\begin{tabular}{|c|c|c|c|}
\hline $\begin{array}{l}\text { Biophysical } \\
\text { parameters }\end{array}$ & $\begin{array}{l}\text { Maximum } \\
\text { value }\end{array}$ & $\begin{array}{l}\text { Minimum } \\
\text { value }\end{array}$ & Description \\
\hline Body height (cm) & 188.0 & 121.9 & \multirow{2}{*}{$\begin{array}{l}\text { Body height and weight are used } \\
\text { to calculate body surface area } \\
\text { (BSA) which is used to determine } \\
\text { the heat exchange between the } \\
\text { body and the environment } \\
\text { (Parson, 2003) }\end{array}$} \\
\hline Body weight $(\mathrm{kg})$ & 87.0 & 27.5 & \\
\hline $\begin{array}{l}\text { Normal Body core } \\
\text { temperature }\left({ }^{\circ} \mathrm{C}\right)\end{array}$ & 37.2 & 36.0 & \multirow{2}{*}{$\begin{array}{l}\text { In heat exposure, an immense } \\
\text { relationship exists between the } \\
\text { physiological mechanisms and } \\
\text { body core temperature. Changes } \\
\text { in core temperature determine the } \\
\text { tolerance level of human being } \\
\text { and hence the vulnerability (Nag } \\
\text { et al., 2013). }\end{array}$} \\
\hline $\begin{array}{l}\text { Change in body core } \\
\text { temp }\left({ }^{\circ} \mathrm{C} / \mathrm{min}\right)\end{array}$ & 0.063 & 0.005 & \\
\hline $\begin{array}{l}\text { Oxygen consumption } \\
\text { (1/min) (predicted) }\end{array}$ & 1.8 & 0.5 & $\begin{array}{l}\text { The total oxygen demand } \\
\text { significantly varies with the } \\
\text { enhancement of environmental } \\
\text { warmth. Increase or decrease of } \\
\text { oxygen demand of one litre was } \\
\text { equivalent to a corresponding one } \\
\text { minute change in tolerance time } \\
\text { (Nag et al., 1997). }\end{array}$ \\
\hline $\begin{array}{l}\text { Clothing insulation } \\
\text { value (clo) }\end{array}$ & 1.2 & 0.2 & $\begin{array}{l}\text { Clothing insulation value is } \\
\text { essential to understand the heat } \\
\text { exchange mechanism between } \\
\text { the skin and clothing surface } \\
\text { (Parson, 2003). }\end{array}$ \\
\hline Work load (watt) & 125.0 & 50.0 & $\begin{array}{l}\text { Metabolic heat production in the } \\
\text { body is significantly related with } \\
\text { the working load. Increasing } \\
\text { workload exacerbate heat load in } \\
\text { the body and therefore decrease } \\
\text { productivity (Nag and Nag, 1992). }\end{array}$ \\
\hline
\end{tabular}




\begin{tabular}{|c|c|c|c|}
\hline $\begin{array}{l}\text { Evaporative } \\
\text { exchange through } \\
\text { skin surface (watt/ } \\
\text { sq.m.) }\end{array}$ & 845.5 & 49.7 & $\begin{array}{l}\text { It signifies the relative change in } \\
\text { the evaporative exchange from } \\
\text { the body surface with the } \\
\text { increasing environmental warmth } \\
\text { (Sen and Nag, 2019). }\end{array}$ \\
\hline $\begin{array}{l}\text { Ambient temperature } \\
\left({ }^{\circ} \mathrm{C}\right)\end{array}$ & 37.0 & 17.0 & \multirow{7}{*}{$\begin{array}{l}\text { These parameters are used in the } \\
\text { assessment of different human } \\
\text { thermal indices }\end{array}$} \\
\hline $\begin{array}{l}\text { Wet bulb } \\
\text { temperature }\left({ }^{\circ} \mathrm{C}\right)\end{array}$ & 30.0 & 15.0 & \\
\hline Relative humidity (\%) & 82.9 & 44.6 & \\
\hline $\begin{array}{l}\text { Dew point } \\
\text { temperature }\left({ }^{\circ} \mathrm{C}\right)\end{array}$ & 28.9 & 13.2 & \\
\hline $\begin{array}{l}\text { Wind velocity }(\mathrm{m} / \\
\text { sec) }\end{array}$ & 2.3 & 0.4 & \\
\hline $\begin{array}{l}\text { Globe temperature } \\
\left({ }^{\circ} \mathrm{C}\right)\end{array}$ & 41.4 & 19.8 & \\
\hline $\begin{array}{l}\text { Mean radiant } \\
\text { temperature }\left({ }^{\circ} \mathrm{C}\right)\end{array}$ & 42.8 & 20.4 & \\
\hline
\end{tabular}

\section{Results}

The social indicators (Table 1) for the individual districts of Punjab and Haryana were treated for statistical analysis to quantify the degree of vulnerability. PCA was done using the SPSS V.20.0 software. 18 parameters were applied to PCA technique using varimax rotation (Kaiser normalization) and therefore, arrived at a quantitative indicator of the social vulnerability of the concerned districts of Punjab and Haryana (Figure 3a), with convergence to a maximum of 10 iterations. The analysis allowed elucidation and determination of the component structure of the dimensions, grouping them into subscales of three components (PC1 to PC3). Each component had an 
eigenvalue greater than 1 . These components were defined as (a) social facilities, (b) agricultural facilities, and (c) demographic structure that had noted influence on social vulnerability.

1. Social facilities (PC1, 3 items) covered the responses that describe the general facilities like domestic electricity, metalled road length and the total main worker, which explained $36.3 \%$ variabilities.

2. Agricultural facilities (PC2, 2 items) included fertilizer consumption and net area under irrigation, explaining $24.4 \%$ of the total variance.

3. Demographic structure (PC3, 2 items) referred to the population density and female literacy rate that explained $23.5 \%$ of the total variance. That is, the three components combined accounted for $84.2 \%$ of the total variance.

The principal components, PC1 to PC3, were analyzed for internal consistencies, by estimating the reliability coefficients (Cronbach's alpha). The reliability coefficients of PC1 and PC2 were high (i.e., Cronbach's alpha values varied in the range of 0.78 to 0.92 ), whereas Cronbach's alpha value was moderate for the demographic structure (0.64), PC3. The component loadings of PC1 to PC3, component score coefficients, and the summated weights of the clustered subjective responses in PC1, PC2 and PC3 are given in Table 4. The product of the component loading of each item with the component score coefficient yielded the individual weights of subjective responses, which were further summated to obtain the weights of $\mathrm{PC} 1, \mathrm{PC} 2$ and $\mathrm{PC} 3$ as $1.03,0.98$, and 0.89 respectively. Accordingly, the respective parameters of PC1, PC2 and PC3 were normalized for each sample using the formulae below to derive coefficients of individual components. 


$$
N_{i}=\sum_{i=1}^{n} \frac{x_{j i}-\bar{x}_{j}}{\sigma_{j}} \times W_{j}
$$

where, $N_{i}=$ Normalized value for $\mathrm{i}^{\text {th }}$ sample; $x_{j i}=$ Actual value of the indicator $\mathrm{j}$ for $\mathrm{i}^{\text {th }}$ sample; $\bar{x}_{j}=$ Mean value of indicator $\mathrm{j} ; \sigma_{j}=$ Standard Deviation of indicator $\mathrm{j}$; and $W_{j}=$ summated weight of the indicator $\mathrm{j}$. The scores of the individual components of the entire sample were $2.30 \pm 1.79$ for $\mathrm{PC} 1,1.32 \pm 1.26$ for $\mathrm{PC} 2$, and $1.30 \pm 0.87$ for $\mathrm{PC} 3$, respectively. The average scores of the three components were transformed to unity to attain a generalized social vulnerability indicator, as below:

$$
V_{S}=0.47 * A+0.27 * B+0.26 * C
$$

where, $V_{S}=$ social vulnerability; $A=$ social facilities; $B=$ agricultural facilities; and $C=$ demographic structure. The summated value of each district was represented further using equal interval scale and pointed as low, moderate, high. Apart from this, the Likert attitude scale values of the social, agricultural and demographic dimensions grouped under $A, B$ and $C$ may be applied to obtain the $S$ value in a scale of five, from 1 , low to 5 , high level of social vulnerability of individual districts for any of such randomized location. 
Table 4. Principal component loadings, component score coefficients and summated weights of different factors describe social vulnerability (Punjab and Haryana)

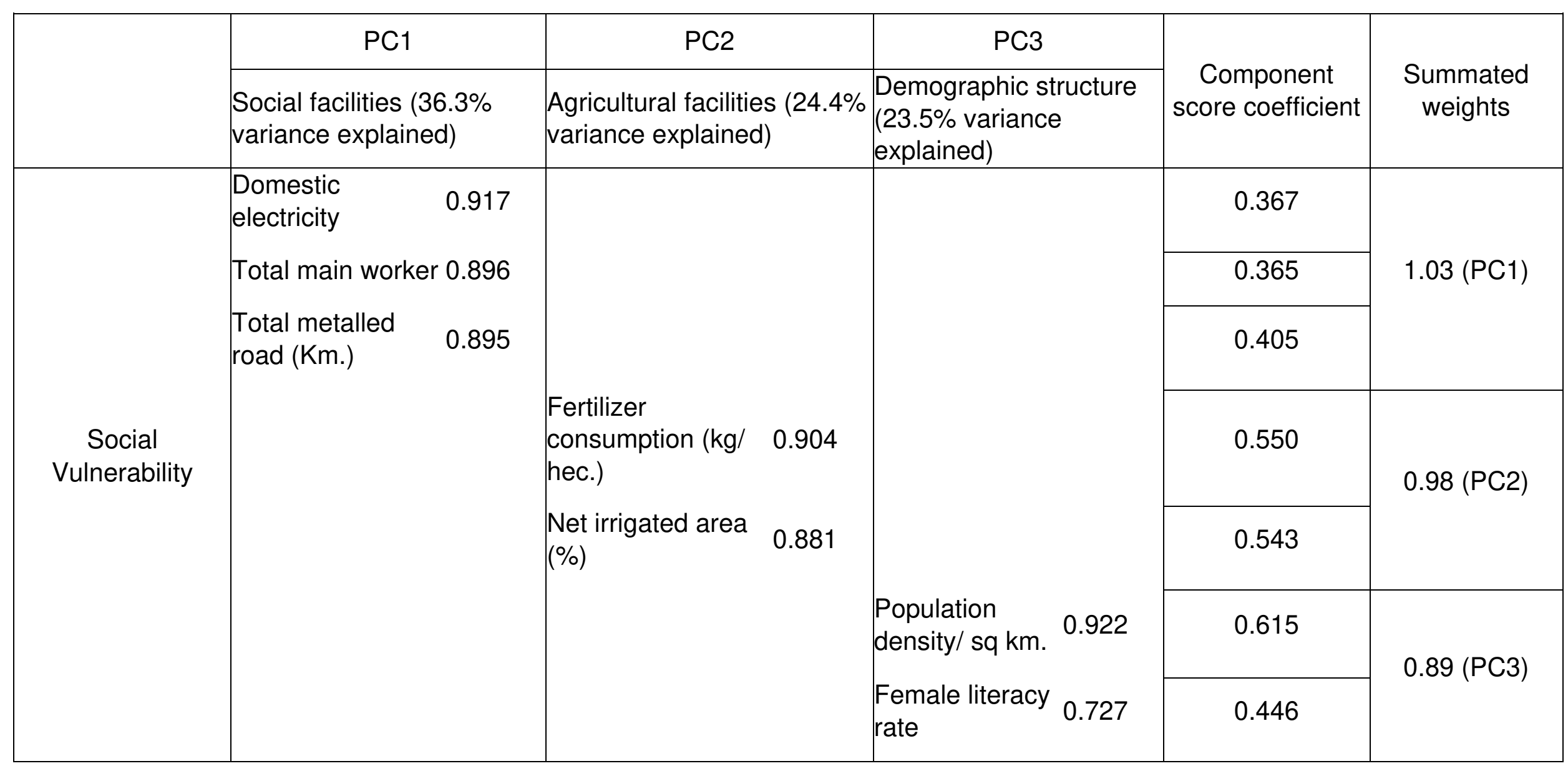


Further, based on WBGT the climatic vulnerability was ascertained for individual districts and depicted as low $\left(<24^{\circ} \mathrm{C}\right)$, moderate $\left(24-28^{\circ} \mathrm{C}\right)$, high $\left(>28^{\circ} \mathrm{C}\right)$ vulnerability (Figure 3b) (Blazejczyk et al., 2012).

Similarly, the cumulative human vulnerability to climate was ascertained, based on the socio-demographic parameters along with the thermal indices, i.e., WBGT, PMV, and SET*. The extracted 3 components were labelled as (a) socio-demographic factors, (b) climatic stressors, (c) farm resources. The factor loadings and weightages of the components are presented in Table 5. These three components explained $87.4 \%$ of the total variance. The Internal consistencies (reliability coefficients as Cronbach's alpha) for PC1 to PC3 were high (i.e., 0.94, 0.99 and 0.72 respectively). The scores of the individual components of the entire sample were $2.98 \pm 2.00$ for PC1, $2.29 \pm 1.87$ for PC2, and 2.16 \pm 1.11 for PC3, respectively. The average scores of the three components were transformed to attain a generalized human vulnerability indicator, as below:

$$
V_{H}=0.40 * J+0.31 * K+0.29 * L
$$

where, $V_{H}=$ human vulnerability; $J$ = socio-demographic factors; $K=$ climatic stressors; and $L=$ farm resources. Based on this method, human vulnerability was obtained for individual districts (Figure 3c) and categorized under low, moderate, high level of vulnerability using equal interval. 
Table 5. Principal component loadings, component score coefficients and summated weights of different factors to describe human vulnerability (Punjab and Haryana)

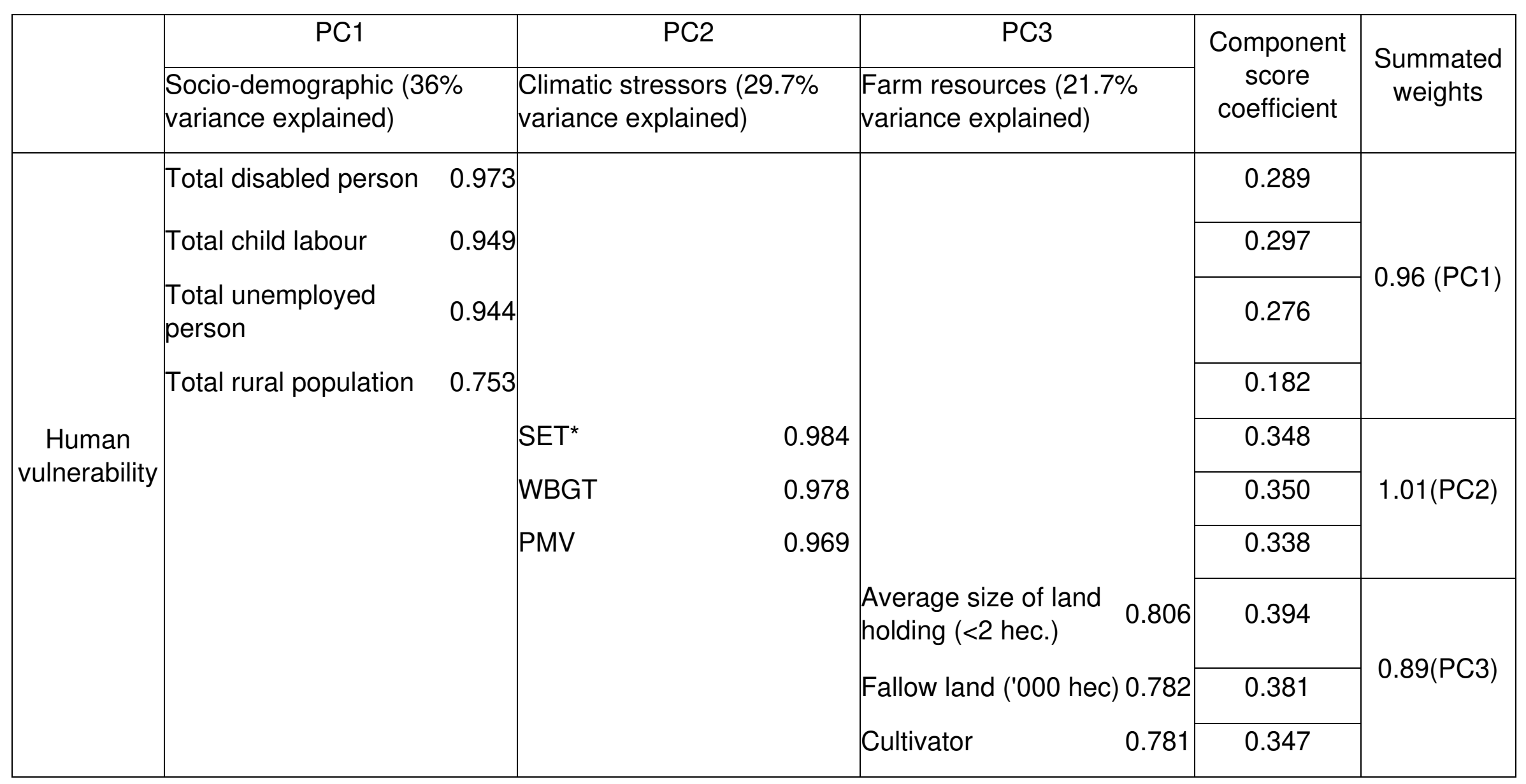




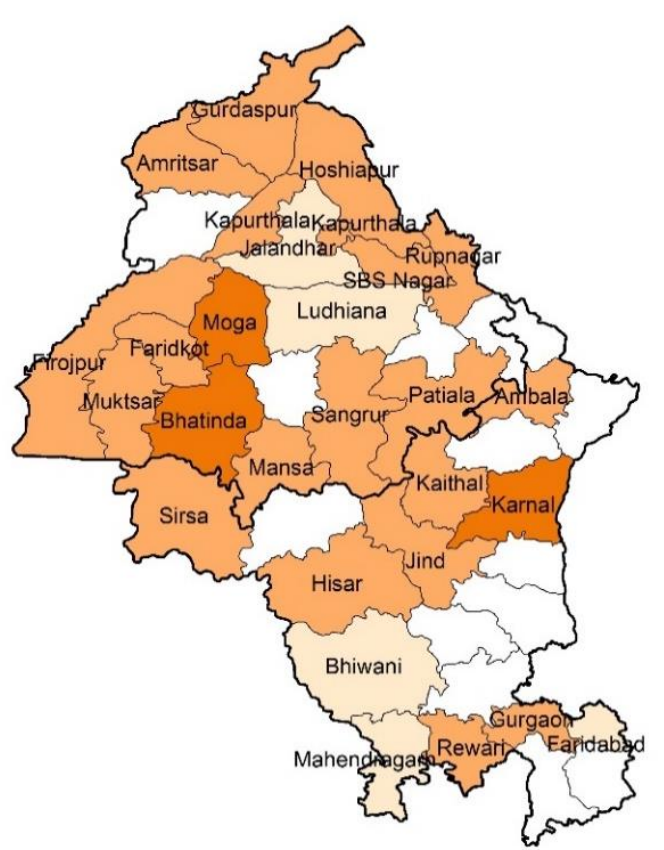

(a)

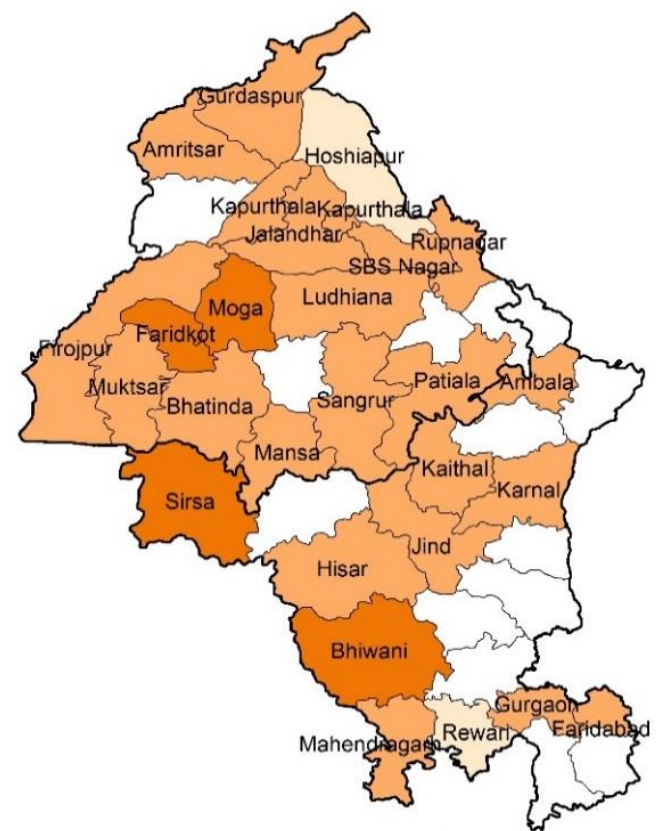

(b)

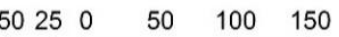

Kilometers

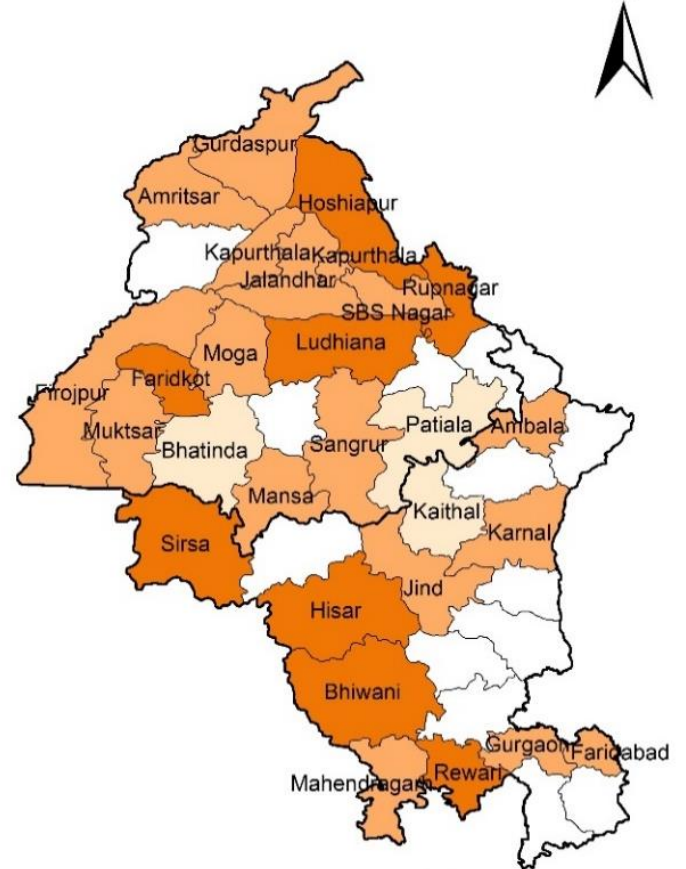

(c)

Degree of vulnerability Low

Moderate

High

Data not available

Figure 3. District wise (a) social, (b) climatic \& (c) human vulnerability in Punjab \& Haryana 
Accordingly, the data of 22 villages of West Bengal were analyzed based on 28 parameters related to the socio-demographic, agricultural and economic status of the villages, mentioned in Table 2. The PCA analysis yielded 3 components, labelled as (a) household amenities, (b) development indicators, (c) basic amenities (Table 6), explaining $72.5 \%$ of the total variance. The reliability coefficients (Cronbach's alpha) were high for the PC1 and PC2 (alpha >0.9) and low for PC3 (alpha 0.15). The scores of the individual components of the entire sample were $7.00 \pm 5.07$ for PC1, $2.37 \pm$ 4.34 for $\mathrm{PC2}$, and $0.62 \pm 0.46$ for PC3, respectively. Thereby, a generalized social vulnerability indicator was attained as:

$$
V_{s v}=0.70 * P+0.24 * Q+0.06 * R
$$

where, $V_{s v}=$ social vulnerability (village level); $P=$ household amenities; $Q=$ development indicators; and $R=$ basic amenities. Based on this method, social vulnerability was obtained for the individual village (Figure 4a) and categorized under low, moderate and high level of vulnerability with equal interval.

Similarly, from 15 indicators describing environmental and biophysical parameters (Table 3), the human thermal vulnerability was ascertained. Village level thermal vulnerability was computed based on the degree of vulnerability of the respondents for individual villages. The extracted 3 components, labelled as (a) environmental parameters, (b) biophysical parameters, (c) body dimensions explained 91\% of the total variance (Table 7), with high (PC1 and PC2 - Cronbach's alpha 0.87 to 0.99) internal consistencies of the clustered dimensions and with moderate consistency for PC3 (alpha - 0.67). The scores of individual components of the entire sample were $2.06 \pm 1.57$ for PC1, $2.24 \pm 1.54$ for PC2, and $1.52 \pm 0.91$ for PC3, 
respectively, from which a generalized human thermal vulnerability indicator was obtained, as below:

$$
V_{H T}=0.35 * X+0.39 * Y+0.26 * Z
$$

where, $V_{H T}=$ human thermal vulnerability; $X=$ environmental parameters; $Y=$ biophysical parameters; and $Z=$ body dimensions. Based on this method, human thermal vulnerability was obtained for the individual village (Figure 4b) and represented as same. The analysis shows differences in the village wise social and thermal vulnerability and supports that socially vulnerable regions might not indicate climatic vulnerable and vice versa. 
Table 6. Principal component loadings, component score coefficients and summated weights of different factors for social vulnerability (Village, W.B)

\begin{tabular}{|c|c|c|c|c|c|c|c|c|}
\hline & \multicolumn{2}{|l|}{ PC1 } & \multicolumn{2}{|l|}{ PC2 } & \multicolumn{2}{|c|}{ PC3 } & \multirow{2}{*}{$\begin{array}{c}\text { Component } \\
\text { score } \\
\text { coefficient }\end{array}$} & \multirow{2}{*}{$\begin{array}{l}\text { Summated } \\
\text { weights }\end{array}$} \\
\hline & \multicolumn{2}{|c|}{$\begin{array}{l}\text { Household amenities (36.9\% } \\
\text { variance explained) }\end{array}$} & \multicolumn{2}{|c|}{$\begin{array}{l}\text { Development indicators } \\
(25.8 \% \text { variance explained) }\end{array}$} & \multicolumn{2}{|c|}{$\begin{array}{l}\text { Basic amenities }(9.8 \% \\
\text { variance explained) }\end{array}$} & & \\
\hline \multirow{15}{*}{$\begin{array}{c}\text { Social } \\
\text { vulnerability }\end{array}$} & \multirow{15}{*}{$\begin{array}{l}\text { Concrete roof } \\
\text { Scooter/ Motorcycle } \\
\text { Latrine facility within } \\
\text { premises } \\
\text { Cement floor } \\
\text { Improved pit latrine } \\
\text { Television } \\
\text { LPG/ PNG fuel } \\
\text { Brunt brick wall } \\
\text { Electric facility }\end{array}$} & \multirow{3}{*}{$\begin{array}{l}0.900 \\
0.864 \\
0.861\end{array}$} & \multirow{15}{*}{$\begin{array}{l}\text { | } \\
\\
\text { Net Area Sown } \\
\text { Female literacy } \\
\text { Total main worker } \\
\text { Canal Area }\end{array}$} & \multirow{15}{*}{$\begin{array}{l}0.976 \\
0.953 \\
0.947 \\
0.906\end{array}$} & \multirow{15}{*}{$\begin{array}{l}\text { Drinking Water } \\
\text { facility within } \\
\text { premises } \\
\text { Drinking water } \\
\text { facility } \\
\end{array}$} & & 0.151 & \multirow{9}{*}{0.99 (PC1) } \\
\hline & & & & & & & 0.160 & \\
\hline & & & & & & & 0.154 & \\
\hline & & 0.807 & & & & & 0.145 & \\
\hline & & 0.790 & & & & & 0.125 & \\
\hline & & 0.705 & & & & & 0.170 & \\
\hline & & 0.689 & & & & & 0.154 & \\
\hline & & 0.658 & & & & & 0.102 & \\
\hline & & 0.652 & & & & & 0.110 & \\
\hline & & & & & & & 0.257 & \multirow{4}{*}{0.93 (PC2) } \\
\hline & & & & & & & 0.245 & \\
\hline & & & & & & & 0.244 & \\
\hline & & & & & & & 0.241 & \\
\hline & & & & & & 0.759 & 0.521 & \multirow[t]{2}{*}{0.40 (PC3) } \\
\hline & & & & & & & 0.066 & \\
\hline
\end{tabular}


Table 7. Principal component loadings, component score coefficients and summated weights of different factors for human thermal vulnerability (Village, W.B)

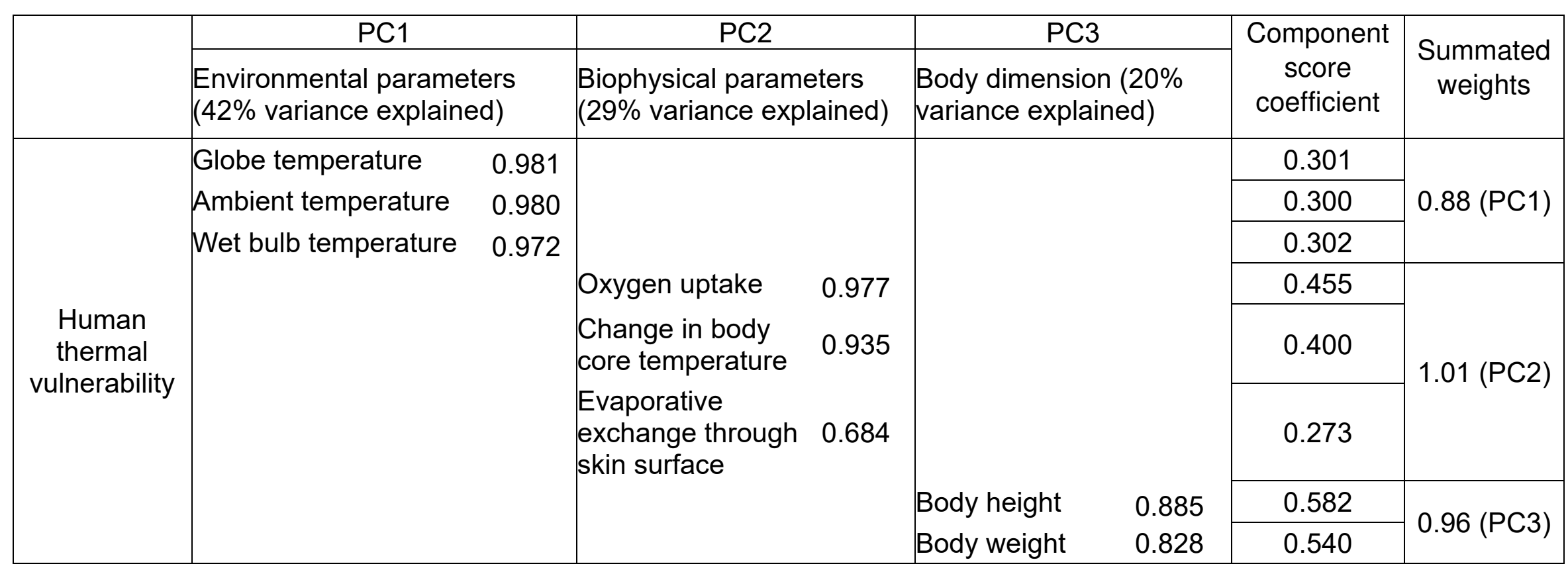




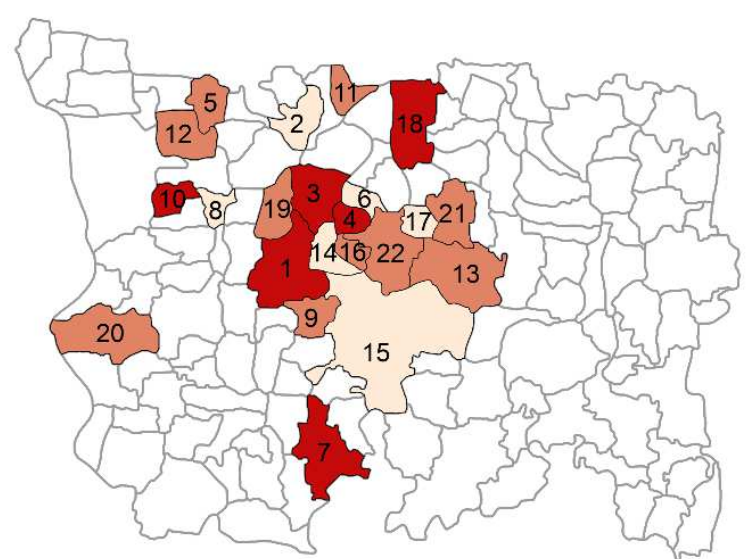

(a)

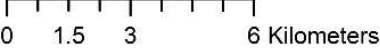

\begin{tabular}{|llllll|}
\hline 1 & Ajodhya & 9 & Chandanpur & 16 & Madhabpur \\
2 & Atpur & 10 & Dakshin Gultia & 17 & Neramadhabpur \\
3 & Bamnagar & 11 & Dharmmapur & 18 & Radhanagar \\
4 & Beli & 12 & Gopalpur & 19 & Raipur \\
5 & Bilara & 13 & Jagannathpur & 20 & Rasidpur \\
6 & Bishnupur & 14 & Jangipara & 21 & Raspur \\
7 & Bornal & 15 & Krishnanagar & 22 & Shirirampur \\
8 & Chaiman Chak & & & & \\
\hline
\end{tabular}

Figure 4. Village wise (a) social and (b) human thermal vulnerability in rural West Bengal

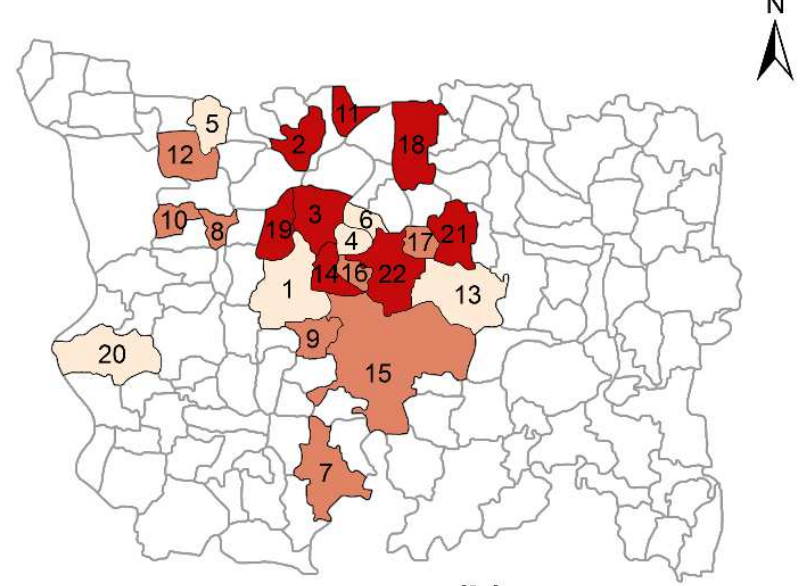

(b)

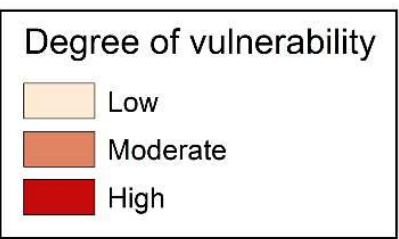




\section{Discussion}

In general, vulnerability refers to the degree of risk towards human lives and properties with adverse climatic condition concerning individual or group of person (McCarthy et al., 2001; Blaikie et al., 2004). In the context of climate change, an intense relationship has been established between the increasing temperature and the degree of vulnerability towards human health and wellbeing, particularly in the tropical and subtropical regions (Kjellstorm et al., 2013). A strong association between heat exposure and mortality has been recorded (Morabito et al., 2006). According to the National Crime Records Bureau, thousands of people each year loss their lives due to heatstroke in India (Dubbudu, 2018). Xiang et al. (2014) established that increase of $1^{\circ} \mathrm{C}$ daily maximum temperature exacerbates heat injury every day by about $0.2 \%$ among outdoor workers in Adelaide, Australia. During the last 15 years (1992-2006) in the United States, about 423 workers in agricultural and nonagricultural industries died due to high heat stress (CDC, 2018). Evidence supports that the higher degree of thermal stress, determined by thermal indices, significantly reduce the productivity of the workers, engaged in diverse farming and allied activities and have a negative implication on health and wellbeing (Watts et al., 2018; Dally et al., 2018). Different health implications, tropical diseases, and job attrition were the commonly identified issues towards the significant loss of workers' productivity in tropical climate (Lundgren et al., 2013). Some recent studies have also estimated the economic cost of productivity loss (Hübler et al., 2008, Zander et al., 2015) which is expected to increase to billions of US\$ in Indonesia, Thailand, Malaysia, Philippines and Vietnam by 2030 (Kjellstorm et al., 2013). In Central Italy, the daytime apparent temperature about 25$28^{\circ} \mathrm{C}$ in summer signified towards increasing heat stress and hence the work-related 
mortality and morbidity (Morabito et al., 2006). Although, in similar climatic exposure human being may experience varied perception and health effects which leads to variation in the vulnerability level (Nikolopoulou and Steemers, 2003; Sen and Nag, 2019b). Over the years various social, agricultural, biophysical parameters have been identified and alternatively used to describe sensitivity and adaptive capacity of the exposed population (Cutter et al., 2000; Wu et al., 2002). However, research is scanty towards the determination of heat related vulnerability considering individual physiological, psychological and behavioural characteristics (Ford et al., 2006; Vincent, 2004). The present study is a modest attempt towards the quantification of human thermal vulnerability concerning human thermal indicators along with social and climatic characteristics of the different region of topical India to explore the degree of vulnerability. The derivation of the relationship of social, human and thermal indicators, is a maiden attempt to reach a quantitative scale of human-thermal vulnerability.

The socio-demographic factors, agricultural parameters were generally used towards the quantitative assessment of social vulnerability in most of the researches. In the present study, social vulnerability was assessed for Punjab and Haryana evolving similar type of parameters. Climatic vulnerability was identified based on the thermal stress, defined by standard heat indices. Further, the degree of human vulnerability was ascertained with the help of social and climatic factors. As described in the results, the social indicators of some districts of Punjab and Haryana states of India were statistically treated using PCA to arrive at a quantitative indicator of the social vulnerability. Three-component structure of the dimensions was defined as (a) social, and (b) agricultural facilities, and (c) demographic structure. The social facilities 
explaining $\sim 36 \%$ of the total variance described the general facilities like domestic electricity supply, availability of metalled road and the total main worker. Fertilizer consumption and net area under irrigation were included under agricultural facilities and explained about $24 \%$ of the total variance. Demographic structure (PC3, 2 items) referred to the population density and female literacy rate that explained $23.5 \%$ of the total variance. Summated weights of the individual principal component were further normalized to derive coefficients of individual components. The average scores of the three components were transformed to unity to attain a generalized social vulnerability indicator. Climatic vulnerability of individual districts was illustrated with the internationally accepted standard of WBGT (ISO 7243: 2003). Further, a group of parameters including socio-demographic and internationally accepted thermal indices were taken into consideration to ascertain the overall level of human vulnerability adopting similar methodology of PCA technique. The extracted 3 components explained $87.4 \%$ of the total variance and were labelled as (a) socio-demographic factors, (b) climatic stressors, (c) farm resources. These three components individually explained $36 \%, 29.7 \%$ and $21.7 \%$ of the total variance respectively. A generalized degree of human vulnerability for each district was derived from the normalized degree of derived coefficients of individual components. Dissimilarity persists among the ascertained social, climatic and human vulnerability level. Analysis reveals that socially vulnerable areas may not be vulnerable towards climatic exposure and hence the degree of human thermal vulnerability, the combination of social and climatic factors, may also differ accordingly.

With the same principle, social vulnerability for 22 villages of West Bengal was ascertained using 28 parameters related to the socio-demographic, agricultural and 
economic status of the villages. Three components marked as (a) household amenities, (b) development indicators, (c) basic amenities, explaining $72.5 \%$ of the total variance resulted from PCA analysis. Apart from PC3, the reliability coefficients were also very high for the PC1 and PC2. A generalized form of social vulnerability was obtained from this analysis. Furthermore, human thermal vulnerability was computed for these villages using 15 environmental and biophysical indicators, collected from the field survey. Village level thermal vulnerability was assessed according to the degree of thermal vulnerability of the respondents for individual villages. In this analysis, three components labelled as (a) environmental parameters, (b) biophysical parameters, (c) body dimensions and explained $91 \%$ of the total variance. A generalized form of human thermal vulnerability was also obtained. The analysis shows differences in the village wise social and thermal vulnerability and supports that socially vulnerable regions might not indicate climatic vulnerable and vice versa. The overall analysis reveals the existing difference in the level of vulnerability over varied time and space. Vulnerability is a relative term and therefore, the degree of vulnerability largely depends on the measured indicators.

WHO emphasized the detrimental effect of heat related specific health hazards and proposed interventions in regional level to prevent the susceptible population (Patz et al., 2005). Implementing appropriate heat prevention plan requires a better understanding of the location-specific spatial pattern with health-related risk (Aubrecht and Özceylan, 2013). An immense relationship has been established among the social, agricultural, biophysical characteristics and overall vulnerability (Cutter et al., 2000; Wu et al., 2002). However, literature supports that quantifying the level of risk associated with the heat-related mortality and morbidity and involving behavioural, 
social and environmental variables is a complex domain to decipher (Harlan et al., 2006). Heat vulnerability research demands thorough investigation and engagement of individual physical and health characteristics irrespective of time and space (Reid et al., 2009). Most of the heat related vulnerability study was documented in Europe and North America, where the plan and strategies were developed at the local level (Azhar et al., 2017). Whereas, heat related health hazards and the resultant vulnerability is yet to be established in developing countries like India (Nag and Nag, 2009) where heavy physical work is common, and the hot season is long (Kjellstorm et al., 2016).

Vulnerability is not a directly observable phenomenon and hence difficult to quantify the level of vulnerability by assigning specific criteria (Luers et al., 2003). A variety of vulnerability approaches and assessment techniques were suggested over the decades based on the relative efficacy and applicability (O'Brien et al., 2004a, Cutter et al., 2003). However, most of the study engaged either in the identification of the most indicative variables or in the assessment of the level of vulnerability in the form of composite index aggregating diverse variables (Hahn et al., 2009; Reid et al., 2009; Johnson et al., 2012) in a parochial manner. Assessment of vulnerability is a complex interaction of environmental, social as well as the biophysical phenomenon and discrepancies might arise from the selection of variables and assigning the relative weights (Gbetibouo and Ringler, 2009). Needless to reiterate that the vulnerability study is in the developing phase undertaking different approaches (Rygel et al., 2006). However, in the context of climatic exposure, physical characteristics cannot alone manifest vulnerability (Wolf and McGregor, 2013). Gaps remain in the micro-level vulnerability assessment (Vincent, 2004) and creating a model for future projection of 
vulnerability over varied climatic regions. Also, there is an obvious need to identify such indicators which can be used globally and may apply to propose a modelling approach (Kelly and Adger, 2000) towards the assessment of human vulnerability. The present analysis is affirmative that the interaction between biophysical and social processes may be suitable for micro to macro-regional (e.g., village and district level) vulnerability assessment. In this analysis, indicators were used to assess different types of vulnerability (such as social, human, climatic and thermal vulnerability). Further stated that any single parameter might not be adequate to determine the degree of vulnerability (Adger et al., 2004; Vincent, 2004). 


\section{References:}

1. Abson, D. J., Dougill, A. J., \& Stringer, L. C. (2012). Using principal component analysis for information-rich socio-ecological vulnerability mapping in Southern Africa. Applied Geography, 35(1-2), 515-524.

2. Adger, W. N., Brooks, N., Bentham, G., Agnew, M., \& Eriksen, S. (2004). New indicators of vulnerability and adaptive capacity. Technical Report 7, Tyndall Centre for Climate Change Research. Norwich.

3. Aubrecht, C., \& Özceylan, D. (2013). Identification of heat risk patterns in the US National Capital Region by integrating heat stress and related vulnerability. Environment international, 56, 65-77.

4. Azhar, G., Saha, S., Ganguly, P., Mavalankar, D., \& Madrigano, J. (2017). Heat wave vulnerability mapping for India. International journal of environmental research and public health, 14(4), 357.

5. Blaikie, P., Cannon, T., Davis, I., \& Wisner, B. (2004). At risk: natural hazards, people's vulnerability and disasters. Routledge, London.

6. Blazejczyk, K., Epstein, Y., Jendritzky, G., Staiger, H., \& Tinz, B. (2012). Comparison of UTCl to selected thermal indices. International journal of biometeorology, 56(3), 515-535.

7. Cutter, S. L., Boruff, B. J., \& Shirley, W. L. (2003). Social Vulnerability to Environmental Hazards. Social Science Quarterly, 84(2), 242-261.

8. Cutter, S. L., Mitchell, J. T., \& Scott, M. S. (2000). Revealing the vulnerability of people and places: a case study of Georgetown County, South Carolina. Annals of the association of American Geographers, 90(4), 713-737.

9. Dally, M., Butler-Dawson, J., Krisher, L., Monaghan, A., Weitzenkamp, D., Sorensen, C., Johnson, R.J., Carlton, E.J., Asensio, C., Tenney, L. \& Newman, L. S. (2018). The impact of heat and impaired kidney function on productivity of Guatemalan sugarcane workers. PloS one, 13(10), e0205181.

10.Dong, W., Liu, Z., Zhang, L., Tang, Q., Liao, H., \& Li, X. E. (2014). Assessing heat health risk for sustainability in Beijing's urban heat island. Sustainability, 6(10), 7334-7357.

11. Dubbudu, R. 2018. 1 out of every 5 Heat Stroke deaths in India occurs in Andhra Pradesh. FACTLY, March, 7. https://factly.in/1-every-5-heat-stroke-deaths-indiaoccurs-andhra-pradesh/

12. Dunne, J. P., Stouffer, R. J., \& John, J. G. (2013). Reductions in labour capacity from heat stress under climate warming. Nature Climate Change, 3(6), 563-566.

13. Dwyer, A., Zoppou, C., Nielsen, O., Day, S., \& Roberts, S. (2004). Quantifying social vulnerability: a methodology for identifying those at risk to natural hazards. 
14. El-Zein, A., \& Tonmoy, F. N. (2015). Assessment of vulnerability to climate change using a multi-criteria outranking approach with application to heat stress in Sydney. Ecological Indicators, 48, 207-217.

15. Fanger, P. O. (1970). Thermal comfort. Analysis and applications in environmental engineering. Copenhagen: Danish Technical Press.

16. Fatemi, F., Ardalan, A., Aguirre, B., Mansouri, N., \& Mohammadfam, I. (2017). Social vulnerability indicators in disasters: Findings from a systematic review. International journal of disaster risk reduction, 22, 219-227.

17. Flanagan, B. E., Gregory, E. W., Hallisey, E. J., Heitgerd, J. L., \& Lewis, B. (2011). A social vulnerability index for disaster management. Journal of homeland security and emergency management, 8(1).

18. Ford, J. D., Smit, B., Wandel, J., \& MacDonald, J. (2006). Vulnerability to climate change in Igloolik, Nunavut: what we can learn from the past and present. Polar Record, 42(2), 127-138.

19. Gagge, A. P., Fobelets, A. P., \& Berglund, L. (1986). A standard predictive index of human response to the thermal environment. ASHRAE Trans, 92, 709-731

20. Gbetibouo, G. A., \& Ringler, C. (2009). Mapping South African farming sector vulnerability to climate change and variability: A subnational assessment. IFPRI Discussion Paper 00885, International Food Policy Research Institute, Washington, DC.

21. Guarcello, L., Mealli, F., \& Rosati, F. C. (2010). Household vulnerability and child labor: the effect of shocks, credit rationing, and insurance. Journal of population economics, 23(1), 169-198.

22. Hahn, M. B., Riederer, A. M., \& Foster, S. O. (2009). The Livelihood Vulnerability Index: A pragmatic approach to assessing risks from climate variability and change-A case study in Mozambique. Global environmental change, 19(1), 7488.

23. Harlan, S. L., Brazel, A. J., Prashad, L., Stefanov, W. L., \& Larsen, L. (2006). Neighborhood microclimates and vulnerability to heat stress. Social science \& medicine, 63(11), 2847-2863.

24. Hübler, M., Klepper, G., \& Peterson, S. (2008). Costs of climate change: the effects of rising temperatures on health and productivity in Germany. Ecological Economics, 68(1-2), 381-393.

25. ISO 7243, 2003, Hot Environments - Estimation of the heat stress on working man, based on the WBGT-index (wet bulb globe temperature). Geneva: International Standards Organisation.

26. Johnson, D. P., \& Wilson, J. S. (2009). The socio-spatial dynamics of extreme urban heat events: The case of heat-related deaths in Philadelphia. Applied geography, 29(3), 419-434. 
27.Johnson, D. P., Stanforth, A., Lulla, V., \& Luber, G. (2012). Developing an applied extreme heat vulnerability index utilizing socioeconomic and environmental data. Applied Geography, 35(1-2), 23-31.

28. Kelly, P. M., \& Adger, W. N. (2000). Theory and practice in assessing vulnerability to climate change and Facilitating adaptation. Climatic change, 47(4), 325-352.

29. Kjellstrom, T., Briggs, D., Freyberg, C., Lemke, B., Otto, M., \& Hyatt, O. (2016). Heat, human performance, and occupational health: a key issue for the assessment of global climate change impacts. Annual review of public health, 37, 97-112.

30. Kjellstrom, T., Briggs, D., Freyberg, C., Lemke, B., Otto, M., \& Hyatt, O. (2016). Heat, human performance, and occupational health: a key issue for the assessment of global climate change impacts. Annual review of public health, 37, 97-112.

31. Kjellstrom, T., Holmer, I., \& Lemke, B. (2009). Workplace heat stress, health and productivity-an increasing challenge for low and middle-income countries during climate change. Global Health Action, 2(1), 2047.

32. Kjellstrom, T., Lemke, B., \& Otto, M. (2013). Mapping occupational heat exposure and effects in South-East Asia: ongoing time trends 1980-2011 and future estimates to 2050. Industrial health, 51(1), 56-67.

33. Krishnamurthy, M., Ramalingam, P., Perumal, K., Kamalakannan, L. P., Chinnadurai, J., Shanmugam, R., Srinivasan, K. \& Venugopal, V. (2017). Occupational heat stress impacts on health and productivity in a steel industry in southern India. Safety and health at work, 8(1), 99-104.

34. Leichenko, R., O’Brien, K., Aandahl, G., Tompkins, H., \& Javed, A. (2004). Mapping vulnerability to multiple stressors: A technical memorandum. CICERO, Oslo.

35. Lin, T. P. (2009). Thermal perception, adaptation and attendance in a public square in hot and humid regions. Building and environment, 44(10), 2017-2026.

36. Luers, A. L., Lobell, D. B., Sklar, L. S., Addams, C. L., \& Matson, P. A. (2003). A method for quantifying vulnerability, applied to the agricultural system of the Yaqui Valley, Mexico. Global Environmental Change, 13(4), 255-267.

37. Lundgren, K., Kuklane, K., \& Venugopal, V. (2014). Occupational heat stress and associated productivity loss estimation using the PHS model (ISO 7933): a case study from workplaces in Chennai, India. Global health action, 7(1), 25283.

38. Matzarakis, A., Rutz, F., \& Mayer, H. (2010). Modelling radiation fluxes in simple and complex environments: basics of the RayMan model. International journal of biometeorology, 54(2), 131-139.

39. McCarthy, J. J., Canziani, O. F., Leary, N. A., Dokken, D. J., \& White, K. S. (Eds.). (2001). Climate change 2001: impacts, adaptation, and vulnerability: 
contribution of Working Group II to the third assessment report of the Intergovernmental Panel on Climate Change (Vol. 2). Cambridge University Press.

40. Morabito, M., Cecchi, L., Crisci, A., Modesti, P. A., \& Orlandini, S. (2006). Relationship between work-related accidents and hot weather conditions in Tuscany (central Italy). Industrial health, 44(3), 458-464.

41. Nag, A., \& Nag, P. K. (1992). Heat stress of women doing manipulative work. American Industrial Hygiene Association Journal, 53(12), 751-756.

42. Nag, P. K., Ashtekar, S. P., Nag, A., Kothari, D., Bandyopadhyay, P., \& Desai, H. (1997). Human heat tolerance in simulated environment. The Indian Journal of Medical Research, 105, 226-234.

43. Nag, P. K., Dutta, P., Nag, A., \& Kjellstrom, T. (2013). Extreme heat events: perceived thermal response of indoor and outdoor workers. International Journal of Current Research and Review, 5(17), 65-78.

44. Nag, P.K., Nag, A., Sekhar, P., Pandit, S., 2009. Vulnerability to Heat Stress: Scenario in Western India. National Institute of Occupational Health, Ahmedabad, pp. 56, Report.

45. Nazrul Islam, A. K. M., Deb, U. K., Al Amin, M., Jahan, N., Ahmed, I., Tabassum, S., ... \& Bantilan, M. C. S. (2013). Vulnerability to Climate Change: Adaptation Strategies and Layers of Resilience-Quantifying Vulnerability to Climate Change in Bangladesh.

46. Nikolopoulou, M., \& Steemers, K. (2003). Thermal comfort and psychological adaptation as a guide for designing urban spaces. Energy and Buildings, 35(1), 95-101

47. NIOSH.(2018). Noise and hearing loss prevention - Guidance and Regulations. https://www.cdc.gov/niosh/topics/noise/reducenoiseexposure/regsguidance.html. National Institute for Occupational Safety and Health, U.S.A.

48. O’Brien, K., Leichenko, R., Kelkar, U., Venema, H., Aandahl, G., Tompkins, H., Javed, A., Bhadwal, S., Barg, S., Nygaard, L., \& West, J. (2004). Mapping vulnerability to multiple stressors: climate change and globalization in India. Global environmental change, 14(4), 303-313.

49. Parsons, K. (2003). Human thermal environment. The effects of hot, moderate and cold temperatures on human health, comfort and performance, 2nd ed. New York: CRC.

50.Parsons, K. (2009). Maintaining health, comfort and productivity in heat waves. Global Health Action, 2(1), 2057.

51. Patnaik, U., \& Narayanan, K. (2009). Vulnerability and climate change: An analysis of the eastern coastal districts of India. 
52.Rao, C. R., Raju, B. M. K., Rao, A. S., Rao, K. V., Ramachandran, V. R. K., Venkateswarlu, B., \& Sikka, A. K. (2013). Atlas on vulnerability of Indian agriculture to climate change.Patz, J. A., Campbell-Lendrum, D., Holloway, T., \& Foley, J. A. (2005). Impact of regional climate change on human health. Nature, 438(7066), 310-317.

53. Ravindranath, N. H., Rao, S., Sharma, N., Nair, M., Gopalakrishnan, R., Rao, A., Malaviya, S., Tiwari, R., Sagadevan, A., Munsi, M. and Krishna, N. \& Bala, G. (2011). Climate change vulnerability profiles for North East India. Current Science, 101(3).

54. Reid, C. E., Mann, J. K., Alfasso, R., English, P. B., King, G. C., Lincoln, R. A., Margolis, H.G., Rubado, D.J., Sabato, J.E., West, N.L. \& Woods, B. (2012). Evaluation of a heat vulnerability index on abnormally hot days: an environmental public health tracking study. Environmental health perspectives, 120(5), 715-720.

55. Reid, C. E., O'neill, M. S., Gronlund, C. J., Brines, S. J., Brown, D. G., Diez-Roux, A. V., \& Schwartz, J. (2009). Mapping community determinants of heat vulnerability. Environmental health perspectives, 117(11), 1730-1736.

56. Rosenthal, J. K., Kinney, P. L., \& Metzger, K. B. (2014). Intra-urban vulnerability to heat-related mortality in New York City, 1997-2006. Health \& place, 30, 45-60.

57. Rygel, L., O'sullivan, D., \& Yarnal, B. (2006). A method for constructing a social vulnerability index: an application to hurricane storm surges in a developed country. Mitigation and adaptation strategies for global change, 11(3), 741-764.

58. Sahu, S., Sett, M., \& Kjellstrom, T. (2013). Heat exposure, cardiovascular stress and work productivity in rice harvesters in India: implications for a climate change future. Industrial health.

59.Sen, J., \& Nag, P. K. (2019a). Effectiveness of human-thermal indices: Spatiotemporal trend of human warmth in tropical India. Urban Climate, 27, 351-371.

60.Sen, J., \& Nag, P. K. (2019b). Human susceptibility to outdoor hot environment. Science of the total environment, 649, 866-875.

61. Tomlinson, C. J., Chapman, L., Thornes, J. E., \& Baker, C. J. (2011). Including the urban heat island in spatial heat health risk assessment strategies: a case study for Birmingham, UK. International journal of health geographics, 10(1), 42.

62. Vezina, K., Bonn, F., \& Van, C. P. (2006). Agricultural land-use patterns and soil erosion vulnerability of watershed units in Vietnam's northern highlands. Landscape Ecology, 21(8), 1311-1325.

63. Vincent, K. (2004). Creating an index of social vulnerability to climate change for Africa. Tyndall Center for Climate Change Research. Working Paper, 56(41).

64. Walker, B. B., Taylor-Noonan, C., Tabbernor, A., Bal, H., Bradley, D., Schuurman, N., \& Clague, J. J. (2014). A multi-criteria evaluation model of earthquake vulnerability in Victoria, British Columbia. Natural hazards, 74(2), 1209-1222. 
65. Watts, N., Amann, M., Ayeb-Karlsson, S., Belesova, K., Bouley, T., Boykoff, M., Byass, P., Cai, W., Campbell-Lendrum, D., Chambers, J. \& Cox, P. M. (2018). The Lancet Countdown on health and climate change: from 25 years of inaction to a global transformation for public health. The Lancet, 391(10120), 581-630.

66. Wolf, T. \& McGregor, G. (2013). The development of a heat wave vulnerability index for London, United Kingdom. Weather and Climate Extremes, 1, 59-68.

67. Wu, S. Y., Yarnal, B., \& Fisher, A. (2002). Vulnerability of coastal communities to sea-level rise: a case study of Cape May County, New Jersey, USA. Climate Research, 22(3), 255-270.

68. Xiang, J., Bi, P., Pisaniello, D., Hansen, A., \& Sullivan, T. (2014). Association between high temperature and work-related injuries in Adelaide, South Australia, 2001-2010. Occupational and environmental medicine, 71(4), 246-252.

69. Zander, K. K., Botzen, W. J., Oppermann, E., Kjellstrom, T., \& Garnett, S. T. (2015). Heat stress causes substantial labour productivity loss in Australia. Nature Climate Change, 5(7), 647-651.

70. Zhao, J., Zhu, N., \& Lu, S. (2009). Productivity model in hot and humid environment based on heat tolerance time analysis. Building and environment, 44(11), 22022207. 